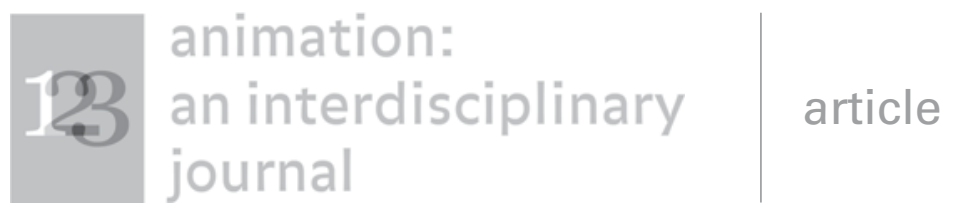

\title{
The Animated Resurrection of the Legend of the White Snake in Japan
}

\author{
Tze-yue G. Hu
}

\begin{abstract}
This article analyses and elucidates the factors involved in the animated reappearance of the Legend of the White Snake in Japan in the 1950s. Driven by the multiple demands of a new post-Second World War era in East and Southeast Asia, where the business of making new images was more urgent, profitable and competitive than ever before, the tale served both micro and macro purposes. Since the legendary tale was well known in the Chinese-speaking world and was initially a joint film project between Japan and Hong Kong, one would have expected the producers (Toei Animation Studio) to envisage the animated tale as primarily for Chinese audiences. However, the Japanese producers had, or later discovered, a wider hidden agenda in making the film that promised more lucrative and geopolitical rewards. Using the concept of 'performativity', this article interprets the course of the animated performance within several dimensions, and traces the history of the foundational role of Toei Animation Studio and its dreammaking enterprise.
\end{abstract}

Keywords animating the fantastic, folktales, Japan and the West, Japan's post-Second World War animation development, joint film projects in the 1950s, performance studies, performativity, Toei Animation Studio 


\section{Introduction}

Odd though it may seem, the post-Second World War industrial development of Japanese animation began with the production of a legendary Chinese tale, one that eventually caught the attention of Western commercial animation producers and affirmed the resources that the Japanese animation industry could offer. This article traces the background of the 1958 animated tale Legend of the White Snake (also known as the White Snake Tale, or in Japanese, Hakujaden) and examines the circumstances of its production, especially in the light of the post-Second World War era and Japan's drive to rebuild a new self-image. It also utilizes the 'concept of performativity' to analyse the 'collective stagey operations' of the newly founded Toei Animation Studio in Tokyo - 'Asia's largest animation studio' (a flattering and selfpromoting description of the Studio found in Toei's early marketing literature).

The findings would suggest that the selection of a popular Chinese narrative and its subsequent animated production was not a random choice but a historical one since it was made at a time when the regions of East Asia, including Japan and Southeast Asia, were emerging from their colonialist past with fresh memories of their 'Imperialist liberator' (Japan) and the horrors it had committed in the Second World War.This article proposes that the animated reappearance of the Legend of the White Snake in Japan in the 1950s was driven by the multiple demands of a new post-Second World War era in these regions, when the business of making new images was more urgent, profitable and competitive than ever before.

The theoretical approach in this article is inspired by the recent work of film historian Donald Crafton, author of Before Mickey: The Animated Film 1898-1928 (1982). In a keynote address in 2002, Crafton reflected that if he could revise the book's content, he would apply the new critical framework of Performance Studies. ${ }^{1}$ The expanding academic perspectives of Performance Studies theories have incorporated the terrains of language, semiotics, psychoanalysis, politics and culture, gender and social-historical materialism studies. For example, the works of Marvin Carlson and Richard Schechner have generated new, far-reaching concepts of performativity and offer more possibilities for theorizing the extensive dynamics of performance. Carlson (2004) acknowledges that the concept of performance can be applied to all human activity, including the perspective that all activity is 'carried out with a consciousness of itself' (p. 4), whereas Schechner (2002) stresses the interrelatedness of performance, as in 'actions, interactions and relationships' (p. 24).

Indeed, a number of early animated films depict the artist-animator at work within the film itself as he 'sketched', 'drew', 'painted' or 'modelled' the image. One example is Gertie the Dinosaur (1914), in which the director and animator Winsor McCay (1867-1934) included 
himself as an actor in the film, overtly showing to the audience his 'animated act' and key participation in the making of the animated frames. The 'hand of the artist' self-figuration motif is an important component in animated performance, not unrelated to the discussion of performance, play, ritualistic repetition and assembly. In this sense, the activity of animation is part of the act of 'showing doing', where Schechner (2002) defined this kind of performance as 'pointing to, underlining, and displaying doing' (pp. 22-44). In acknowledging Schechner's cultural anthropological basis in explaining the activities of performance, Crafton (2003[2002]) foregrounds Schechner's encompassing definition: 'The underlying notion is that any action that is framed, presented, highlighted or displayed is a performance' (p. 2).

Thus Crafton argues that 'at the heart of all classic animation ... several kinds of performance converge': one is 'performance in animation' and another is 'performance of animation'. While Schechner highlights key phrases like 'what is to perform', 'what is a performance', 'functions of performance' and so on, Crafton narrows the scope to two essential prepositional properties of classic animation: distinguishing 'performance in animation' as 'performances represented by artist animators' and 'performance of animation' as 'the practice of creating animated film'.

My analysis of the animated production of the Legend of the White Snake rests theoretically on these two performance categories as proposed by Crafton. However, the 'nationalistic collective component' will be emphasized as the overall animated performance is interpreted as epitomizing a corporate cultural stance which should not be overlooked. It concerns more than just 'large-scale institutional behavior' ( $p$. 11) and investigates the existence of a collective yet personal and unconscious performative attempt to redeem a lost innocence and a darker past. Disappointingly, somewhere in the performative process, the animated tale lost its intended original target audience (the Chinese-speaking communities) and became a means to an end to serve other corporate and geopolitical purposes. This article therefore locates the animated folktale in the transactional crossroads of a juncture in time. It also acknowledges the producer Toei Animation Studio and its determined investment of talent, finances and other resources in the business of 'dream-building', regardless of the obstacles or contending odds that might be thrown up in the process.

\section{What is the Legend of the White Snake?}

The Legend of the White Snake is a popular vernacular Chinese folktale, which dates back to the Tang Dynasty. Originally, it was a moral story about a man's adulterous affair with a white snake, disguised in human form, and the man's subsequent death, when he is reduced to liquid and bones upon returning home. The narrative 
content of the folktale underwent numerous changes through the ages: during the Song Dynasty, the innocent sexual desire of the male protagonist was emphasized, while during the Ming dynasty, both Madam White Snake and her human male partner (see Figure 1) were depicted as adversaries of the normal social order and accepted code of behaviour. The ancient tale also included the increasingly supporting role of Qing Qing (see Figure 2), the snake's companion fish-sister, and the powerful didactic Buddhist monk Fa-hai (see Figure 3), who finally locked up the two creatures in the monastery's pagoda. By the Qing Dynasty, this vernacular tale 'humanized' Madam White Snake further and recounted her abilities to give birth to a son and to serve her husband and her community. In 1956, the communist-governed People's Republic of China (PRC) printed a new version of the tale. This time, the feudalistic elements of the tale were emphasized by the author Zhao Qingge, ${ }^{2}$ including the weak role of the male protagonist $\mathrm{Xu}$ Xian and his final transformation into a strong and unwavering character in the face of challenges and struggles (Huss, 1997).

The Japanese animated portrayal of Hakujaden is a mixture of the Ming, Qing and PRC versions of the tale and, interestingly, the Japanese producers' own interpretations. Especially in relation to the latter, the conclusion of the tale shows Madam White Snake and $\mathrm{Xu}$ Xian gaining the understanding and sympathy of the Buddhist

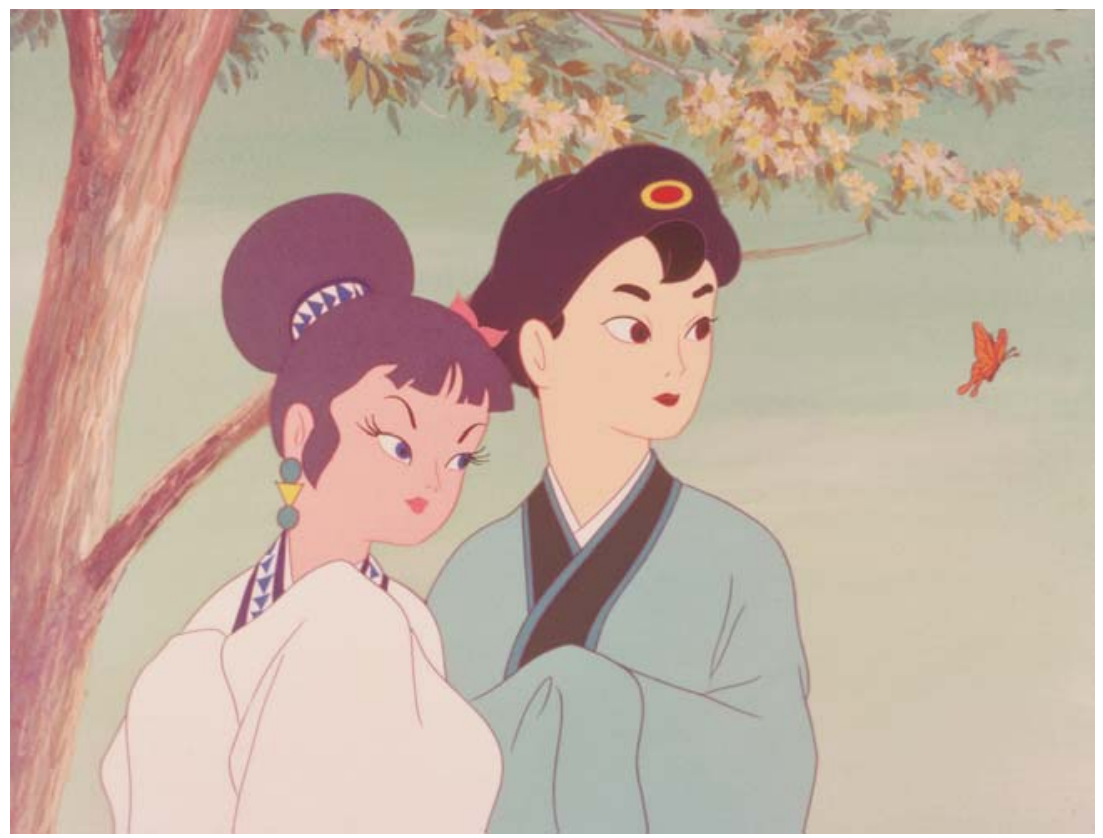

Figure 1 Madam White Snake and Xu Xian. (c)Toei Animation. Reproduced with permission. 


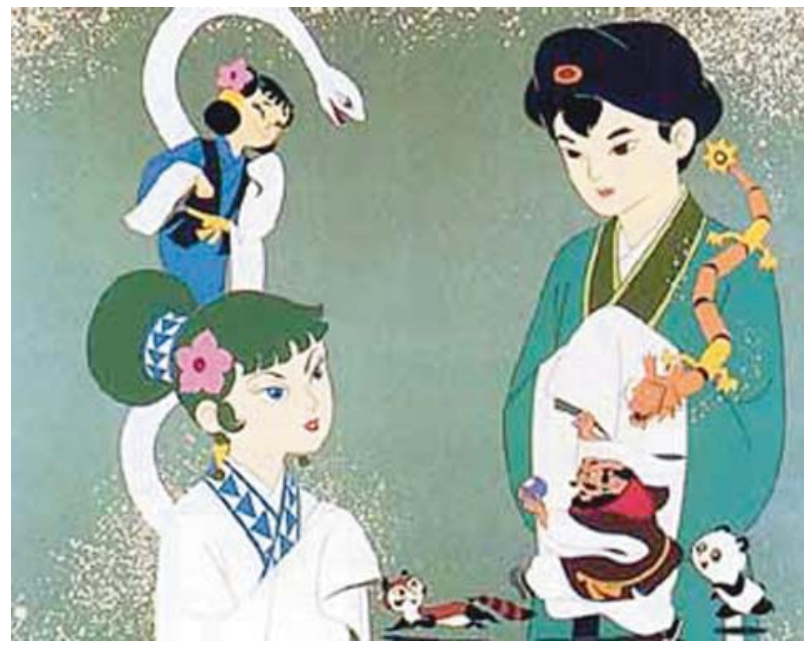

\section{Figure 2}

Other Legend of the White Snake characters: Qing Qing, Panda and his group of friends. (C) Toei Animation. Reproduced with permission.

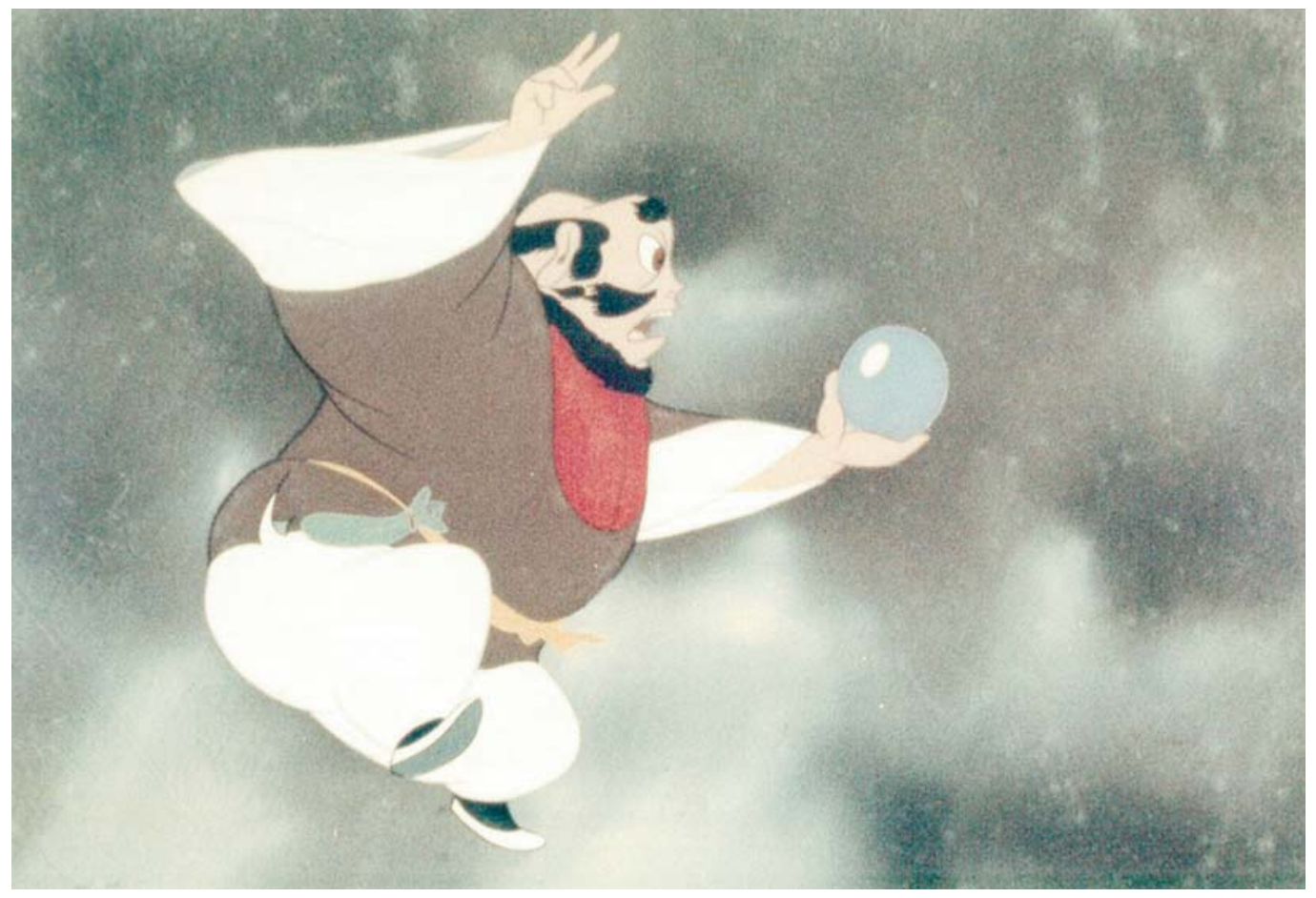

Figure 3 Buddhist monk, Fa-hai. (c)Toei Animation. Reproduced with permission.

monk Fa-hai as they decide to embark on a new future together. In the Chinese version, as shown in the live-action films made in 1962 in Hong Kong, 1978 in Taiwan, and again in 1993 in Hong Kong, the conclusion is unavoidably tragic; there is always separation, and 
possibly death. Historically, Hakujaden was already known to the Japanese during the Edo period (1603-1867), and it was classified as a yomibon tale in which 'Japanese images, texts and history' were woven into the original Chinese narrative (see Shirane, 2002: 565-7, 583-98). But the 20th-century animated version has not adapted the Japanese yomibon tale; none of the images bear any signs of a Japanese setting. ${ }^{3}$ Rather, it encompasses the technicoloured world of a far-away land and its distinctive representations, including the names of the featured characters. Why is this?

\section{Founding of Toei Animation Studio}

The background of the founding of Toei Animation Studio (officially known as Toei Animation Company) in 1956 can be partly explained by the tremendous rise of film production activities in Hong Kong in the 1950s. For example, it was reported that in that decade alone, Hong Kong 'produced over 2,175 films' (Overseas Chinese Figures in Cinema, 1992: 24). In 1962, over 250 films were made in Hong Kong alone, 'more than that of US and Britain combined' (Thompson and Bordwell, 1994: 462). The film conglomerate Tokyo Motion Picture Distribution Company (or Toei for short) ${ }^{4}$ was a relative latecomer to the film industry in Japan and Asia. In order to forge an identity in the film production scene, its founder, Okawa Hiroshi (1897-1971), had also invested in building a Disney-style animation studio with multitasking facilities.

In need of an investor, Toei subsequently approached a Hong Kong producer, Zhang Guoli, to sponsor the project. Throughout the $1950 \mathrm{~s}$ and 1960s, well-established film studios such as Shochiku, Toho and Daiei also cooperated with Hong Kong film companies. They had close connections with cinema operators in various parts of Asia, thus making available a vast hinterland of Asian audiences to Japanese producers looking for nearby overseas markets in which to distribute their films. Several joint, expensive film projects on epic Chinese historical tales were produced and, on the Japanese side, the enthusiasm even spilled over into live theatrical productions - for example, Takarazuka, which was a highly successful, popular, all-female operetta company in Japan.

Among the live-action, joint film projects was the Madam White Snake (in Japanese, Byaku fujin no yōren), produced by Toho and Shaw Brothers in 1956. The production cast was entirely Japanese, including the main actress Yamaguchi Yoshiko, who also had a Chinese name, Li Xianglan, and was a familiar star in the Chinese-speaking communities in East Asia and Southeast Asia. The film credits Shaw Brothers for consultative supervision of the project, but it is likely that the Hong Kong producers provided supervision of the script-narrative development and the indoor filming (Yau, 2000: 106) 


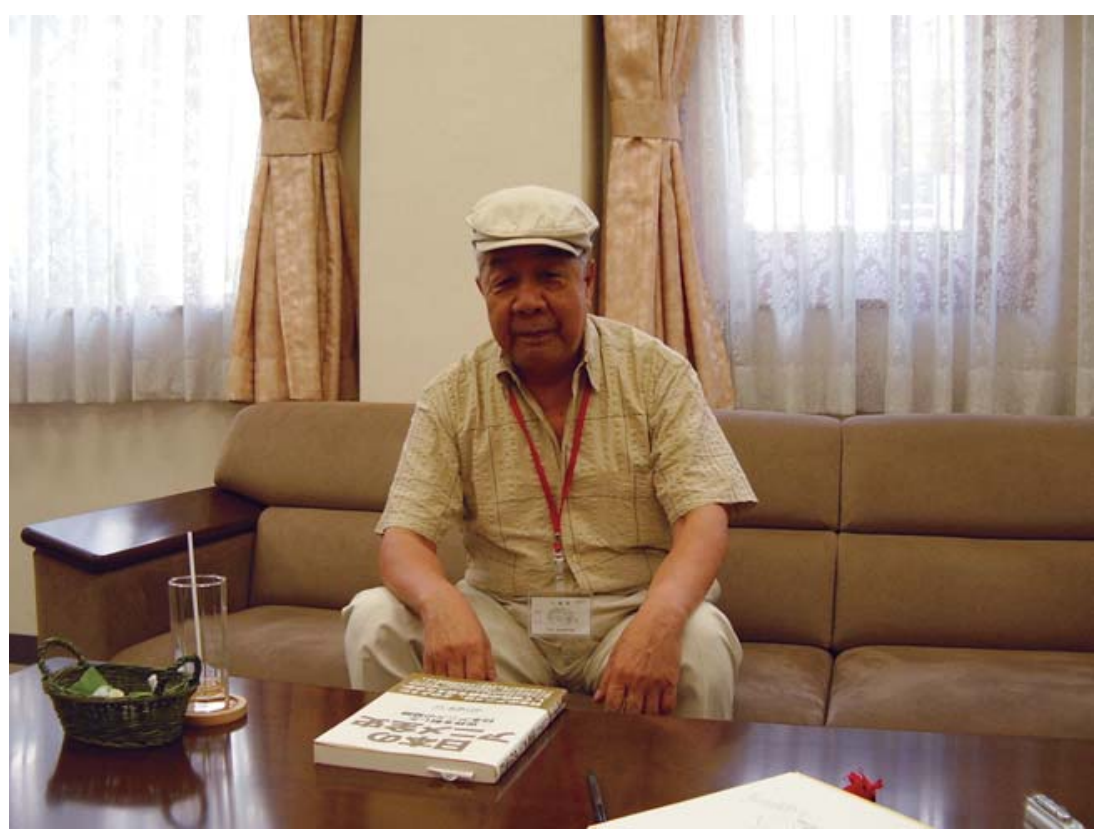

Figure 4 Otsuka Yasuo, a senior staff member of the Hajukaden production team. (c) Tze-yue G. Hu.

and left the responsibility for the other parts of the production to the Japanese production crew. ${ }^{5}$ However, in the animated version of the Legend of the White Snake produced by Toei, several distinguishing features were introduced into the film that demonstrated the cultural differences of these two neighbouring countries, their differing historical-psychological mindsets and the producers' conflicting perspectives on the medium of animation. Hong Kong's coparticipation in the project was never realized; according to one veteran Japanese animator Otsuka Yasuo (see Figure 4), the partnership came to a halt due to arguments regarding the target audience and the narrative content of the story. ${ }^{6}$

\section{Is animation a storytelling medium where 'everyone lives happily ever after'?}

As mentioned earlier, the Legend of the White Snake is not a literary piece of work penned by a specific author - it is a chuanqi and its Chinese title is Basbechuan, meaning the 'legendary folktale of the White Snake'. In other words, the story has been passed on from generation to generation as a narrative of extraordinary events. By the early Qing Dynasty (1644-1911), the tale had become a popular text in opera and tanci, a form of storytelling accompanied by stringed 
instruments. (Like opera, tanci was often performed in public teahouses and at other social gatherings.)

Since the Tang Dynasty and in every dynastic period that followed, the tale became progressively more critical of the roles of the Taoist priest (he is a less powerful figure and is nameless) and the Buddhist monk Fa-hai, who paradoxically became a treacherous figure and the most disliked religious character featured in the story. In 1956, when the full story appeared in book form, author Zhao Qingge decided to conclude the tale by bringing about the reunion of Madam White Snake and her loved ones, but the menacing existence of Fa-hai still looms behind it. In the 1990s, the tale was retold by Hong Kong writer Li Bihua, giving a bigger role to the Green Fish Qing Qing. In the subsequent live-action film adaptation of Li Bihua's version, director Tsui Hark emphasized Madam White Snake and Qing Qing's unending feud with Fa-hai. Hence, Fa-hai was never portrayed as a benevolent fatherly figure capable of remorse, compassion, or redemption. On the contrary, he remained a corrupt, self-righteous, hypocritical and authoritarian figure, imposing his demands and views on those whose actions he deemed immoral, or wrong.

In the animated version of the Legend of the White Snake, the Japanese producers literally bring the age-old vernacular tale to a close by portraying Fa-hai as a 're-born' Buddhist monk. He shows compassion and remorse for his past actions and judgemental behaviour and at the end even helps the long-suffering couple to overcome their ordeal (which he had created in the first place). Until the late 20th-century Chinese version of the Legend of the White Snake, the male protagonist Xu Xian was still largely portrayed as a weak male character in terms of his physical abilities and mental make-up. Time and again, because of his indecisiveness, suspicion and selfishness, he betrays the love of Madam White Snake and her sacrifices. However, in the 1956 book version, in which author Zhao Qingge portrays him as a stronger male character, his frequent foolish and unintelligent moves are often reversed by the timely interventions of his female companions, namely, Madam White Snake, Qing Qing and even his sister-in-law. Hence, the Legend of the White Snake is not a typical romance in which the male gender is portrayed as heroic, gallant and chivalrous. On the contrary, as represented by $\mathrm{Xu} \mathrm{Xian}$, the male protagonist possesses the opposite characteristics: effeminacy, weakness and relative poverty in material terms - in fact, an average, ordinary male despite his good looks. ${ }^{7}$ He may be passionate and lustful, which explains his attraction to the beautiful Bai Niang or Pai-nyan (Madam White Snake in Chinese and Japanese, respectively), but he is also dependent on her for charting his career and achieving a healthy, meaningful family life.

In the Japanese-made animated film, Xu Xian, like the Buddhist priest Fa-hai, acquires a completely different set of qualities as the tale draws to a close. Towards the end of the film, as the narrative reaches 
a climax, Xu Xian becomes a strong swimmer and life-saver as he races to rescue the drowning Pai-nyan, who has lost her special powers. ${ }^{8}$ Thus, he becomes a heroic male protagonist not unlike a Disneyesque Prince Charming arriving dramatically to save his beloved damsel in distress. The animated tale concludes with the couple sailing away into calm waters as they begin a new life together. It is a classic conclusion, dutifully affirming the 'and they lived happily after' ending.

Herein lie the ideological questions about the medium of animation. Must it ultimately portray a wholesome 'all is well' world in keeping with the childlike, innocent and illustrative world of creation? Or should it leave the 'uncanny' open, as the medium itself carries with it a sense of the fantastic and the magical? How much consideration should the production team pay to its intended ethnic audience, taking into account the illustrative, make-believe world of animating? Is there a set of formulaic representations, actions and behaviours to follow and 'create' when making a cel-animation-based commercial feature film? Examining the context of the animated production of the Legend of the White Snake, it seems to point to a calculated course of creation, a course that had already been tested and demonstrated by a much-admired, geographically distant party, most notably the institution of Disney films. Moreover, between 1948 and 1954, many previously banned foreign-made films were screened in Japanese cinemas, reviving popular interest in Disney films. Thus, films like Snow White and the Seven Dwarfs (1937), Pinocchio (1940), Dumbo (1941), Bambi (1942), and Cinderella (1950) were finally shown to Japanese audiences (Yamaguchi and Watanabe, 1977: 60).

\section{Performing to 'impress', to 'heal' and to 'become'}

It is plausible that these questions drove some of the underlying considerations when The White Snake's joint sponsors and producers pondered the narrative development of the proposed adaptation. One could even speculate that by the early 1950s, Hong Kong film producers and other potential film distributors in the region had become aware that Japanese film producers were in urgent need of regional and international markets. In her paper 'Hong Kong and Japan: Not One Less', Yau (2000) gives the impression that Hong Kong producers, particularly the Shaw Brothers, were actively involved in promoting joint cooperative works between the Japanese and Hong Kong film industries (p. 106). From a Hong Kong perspective, Yau is correct in pointing out that 'the co-productions offered a good chance to learn about Japanese technology and to open up the Japanese market'. However, the growing size of Shaw Brothers' multi-national film distribution network in Asia and that of other Chinese film companies should not be underestimated; the Japanese film industry intrinsically recognized the wide distribution networks that were available. 
In relating the history of the Japanese film industry, Anderson and Richie (1982: 248) note that Japanese film producers, in trying to sell their film products abroad in the 1950 s, promoted the idea of coproduction. Besides approaching American and European film producers and directors, Hong Kong producers were also contacted and proposals were made. ${ }^{9}$ Perhaps a more effective tool for understanding the resurrection of the White Snake Tale in Japan and its presentation in animated form can be found in the archives of the Eiga Nenkan (Motion Picture Almanac), compiled by the Japanese Film Producers Association. ${ }^{10}$ Another research source is Taiwanese film critic Lu Feng's paper (1980), which describes the post-Second World War exhibition network of Asian films. Lu Feng states that Japanese film producers, led by Daiei's president Nagata Masaichi, in addition to wanting to promote Japanese-made films in Asia, wanted to correct the past negative, militaristic image of Japan by means of culture and the arts. Lu notes that after the Second World War, a number of countries in Asia tried to rebuild by focusing on cultural development. But in the field of film production and in recognizing the cultural status and value of film-making, Japan was 'quick in assuming leadership' (p. 197). Thus, in 1953, the Southeast Asia Motion Pictures Producers Association was formed under the leadership of the Japanese film producers with the support of Hong Kong film producers, notably the Shaw Brothers. And in 1954, the first Southeast Asia Film Festival (later known as the Asian Film Festival) was held at Tokyo with the first participating members of Japan, Taiwan, the Philippines, Hong Kong, Thailand and Malaysia (including Singapore) exhibiting their respective domestic-made films. The Eiga Nenkan dutifully reported on such gala film events and joint film projects. But when the animated version of the White Snake Tale was completed, its title failed to appear on any of this regional film festival's programme lists: neither the Eiga Nenkan or Lu Feng's paper mentions the exhibition of the animated film in the region's much-publicized film festival.

As discussed earlier, the Hong Kong producer's disagreement with the script development was one factor; another explanation might be the view that animation was considered a lesser medium. Examining the history of the Asian Film Festival from 1954 to 1970, for example, it becomes apparent that other member-country participants submitted few, if any, animated films. Yet time and again, the Japanese submitted animated films in competitive categories of the festival. The Shaw Brothers' company, a participating member of considerable influence, did not produce any animated films. However, on the Japanese side, right from the inception of the planned joint-film project around mid-1956, production of the White Snake Tale was widely reported on in the local media (Otsuka, 2001: 30). Perceptively, the Japanese producers recognized the strategic performative power of animation in the aftermath of a world war.

A portion of the 1958 yearbook of the Eiga Nenkan is devoted to 
the examination of films as an important leisure activity for children and young people in Japan. With the establishment of the seishōnen eigashin gikai, a discussion group formulating the film industry's responsibilities for providing entertainment for the young, it was decided that for young people between the ages of 15 to 18 (attending upper secondary to pre-university studies), films should be made for their stipulated category seinenkō (directed towards older adolescents). Children attending primary school and lower secondary school should be watching films made for the category shōnenkō (directed towards children and younger adolescents). Especially for the seinenkō category, the following film production aims were formulated (my translation):

1 to cultivate the appreciation of aesthetics and heighten the awareness of noble and positive emotions;

2 to promote concern and discussion for the development of society;

3 to promote appropriate knowledge and cultivate a deep understanding of ethics;

4 to educate for a love of humanity;

5 to make lively entertainment films for positive reactions.

Toei, in marketing itself as a newly established postwar film company, also tried to create a 'brand niche' through its production of children's and animated films with educational and cultural value. In the period from 1956-8, while the production of the animated White Snake Tale was in process, the parent company promoted its plan to set up a three-storey animation studio that would house the latest in stateof-the-art technology, complete with air-conditioning, in a concrete building complex. In the words of the studio's founder Okawa Hiroshi, 'we shall progressively produce and recreate American-Disney's professional standard of animated films' (Eiga Nenkan, 1960: 332).

In 1958, when Hakujaden was completed and screened in Toei's chain of commercial cinemas in Japan, it attracted the attention of many talented high school and university graduates. Produced in Eastman color (rather than in its own country's brand, Fuji colour), this 78-minute feature film - comprising over 200,000 cel-drawings and other exquisite artwork and hailed as the country's first full-length colour animated feature film - attracted job-hunting graduates from prestigious universities in Japan. Majoring in such diverse subjects as French literature, economics, accounting, business administration, film studies, Japanese and Western art, and so on, they competed for job openings offered by the studio. Among them were Miyazaki Hayao and Takahata Isao, who were to make historical contributions to the development of Japanese animation in the latter part of the 20th century. In other words, the resultant sakubin (the performed work), together with the corporate image that the parent company had 
promoted, had the power to 'impress' and attract precisely the talents that the ambitious animation studio needed. In 'showing' and 'exhibiting' its capabilities in producing work of Disney standards, the studio also hoped to attract recruits drawn to the senior training staff and the skills of experienced animators, whom the management had earlier employed. ${ }^{11}$

Animation scholar Maureen Furniss (1998: 17) writes that cel-based animation has an assembly-line application as the Taylor-like form of scientific management ensures standardized processes in mechanization and labour-intensiveness. ${ }^{12}$ In the context of the establishment of Toei Animation Studio, the adoption of such management economics and animation production methodology fitted the post-Second World War, nation-building image of Japan. From the management's perspective, the 'dream-studio' provided jobs, and the products it aimed to create were for the re-building of a 'happy national life' (Eiga Nenkan, 1960: 333). But at a deeper level, in the recesses of many Japanese minds were memories, regrets, disappointments and unresolved issues regarding the large-scale, prolonged war fought in the first half of the 20 th century. ${ }^{13}$ Therefore, many of the administrative and production staff members saw the studio as a kind of 'rebirth' place for them in which they could 'perform' a contributory role in building a new kind of future for the current generation of children.

Many of Toei's new recruits who joined at the end of the 1950s had experienced the devastation of war when they were children; some were too young to serve in the military, and others were called up to serve towards the end of the war. Collectively, the performative component of the studio served several dimensions, which were interwoven with intense personal self-healing. In its workers' attempts to recover a lost innocence or childhood, and by participating in the childlike world that they had lost (as many were under the spell and actions of imperialistic ideology), the studio was regarded as a communal place to realize goals of modernization. This observation is based on my interviews with a number of retired and veteran Toei staff members in Tokyo from September 1998 to March 2000 and August 2003 to July 2004.

Where the animated narrative of the White Snake Tale is concerned, it may seem hasty to propound the idea that the 'happily ever after ending' is a deliberate pro-Disney choice; however, a case can be made for this viewpoint, as I will elaborate on in my conclusion. For now, I simply want to advance the notion that the positive ending of the animated tale - particularly the compassion, remorse, and changed behavior displayed by Buddhist priest Fa-hai - can be explained as a kind of Jungian psychoanalytic act, indirectly symbolizing Japan's nationalistic desire to recognize its past erroneous actions, to be forgiven, and to be given a chance to reform. Culturally, it could also be argued that the Japanese have a different perspective on a monk's lifestyle. In contrast to Indian and Chinese Buddhism, a 
Japanese Buddhist monk is allowed to have a family life if he so chooses and, like his fellow Shintō priest, his religious duties and responsibilities can be hereditary. In the Japanese case, Fa-hai's final ability to understand the man-woman relationship of Xu Xian and Pai-nyan was not a far-fetched development. ${ }^{14}$ Therefore, although Yabushita Taiji (1901-86) was the director and the scriptwriter of Hakujaden, the narrative content of the animated story was a collective work. Furthermore, certain prominent animated segments of the film were supervised by the late Mori Yasuji (1925-92), who is remembered for his symbolic 'happy animal communities', which he himself often designed and animated.

In Hakujaden, for example, Panda and his group of animal friends and their various good deeds and friendship were created and chiefly designed by Mori. Applying psychoanalytic theory to Mori's early postSecond World War illustrated works, Yokota Masao (2004) argues that Mori chose the artistic path of animation in his search for salvation, peace and happiness. Mori Yasuji was a much-respected senior training staff member in Toei during the foundational period. In interviews that I conducted for this research, many retired Toei members considered him the 'best animation teacher', who had touched their lives in many ways - through his animated work, his kind and respectful demeanour, his dislike for authoritarian behaviour, and his unselfish willingness to impart animation skills to others. ${ }^{15}$

Returning to Carlson's (2004) and Schechner's (2002) studies of performance, Carlson stresses the presence of 'consciousness' in performing and doing and that the quality of performance lies in the 'attitude'. Schechner, by contrast, accentuates the 'relative' and 'interactive' nature of performance. At Toei, at the individual level, staff members made use of the animation medium to achieve certain personal and collective goals in fulfilment of their idealistic perspective on the medium. However, on a corporate basis, the studio related the medium to the international level whereby certain nationalistic and business ends could be achieved. From the broadest perspective, in choosing to animate a popular Chinese tale and promote it as a joint film project, the studio could be seen as taking part in Japan's intention to present a changed image to the international world and to make new overtures to a neighbouring culture, which the country had admired for centuries despite the atrocities Japan had committed in the earlier part of the 20th century.

Until recently, Chinese communities in East Asia and Southeast Asia were hardly aware of the Japanese-made animated version of the White Snake Tale, although several live-action films were widely known. According to the present senior managing director of the studio, Yoshioka Osamu, the film was shown in Southeast Asia when it was on international release. ${ }^{16}$ Yamaguchi and Watanabe (1977: 66) mention a report stating that Okawa Hiroshi contacted a Hong Kong film distributor for possible screening opportunities in that region, 
promising that dubbed versions would be made in several Chinese dialects. However, it is unclear whether the film was ever shown in that part of the world since Japanese-made films were banned in Korea and Taiwan in the decades following the Second World War. In other parts of Southeast Asia unless the films were internationally acclaimed (such as Rashömon, 1950, and The Seven Samurai, 1954, directed by Kurosawa Akira, and Tokyo Story, 1953, directed by Ozu Yasujiro) or were marketed as successful joint-projects, e.g. with the Shaw Brothers' film company, the region on the whole was not enthusiastic about importing Japanese films. During that time, the region was generally suspicious of films made in Japan due to the country's past militaristic actions. ${ }^{17}$ In Eiga Nekan, there were also occasional reports documenting the Japanese contingent's fear when the film festival was held in some of the Southeast Asian cities. Sensitively, the participating Japanese members were concerned with the warui kuni ('bad country') image that Japan had acquired from the Second World War.

On the other side of the globe, however, where there were fewer direct and painful memories of Japanese imperialism, North America and Europe gave a less complicated reception to the animated tale. In fact, it was the colour-animated version of the White Snake Tale that launched Toei as a force in international commercial animation production. The studio effectively promoted this flagship film in international film festivals in Europe, where it received several awards. ${ }^{18}$ Strategically, Toei was steadfast in recognizing the exotic nature of the legendary tale, especially in the eyes of Western viewers. For example, at the Berlin Film Festival of 1956, the live-action film version had already received a special award for its photographic colour effects (Eiga Nenkan, 1957: 149). It can be inferred from Toei management's long-term vision that the studio was covertly courting the American market. The Eiga Nenkan recounts that Toei's executives visited the United States on several occasions to solicit joint cooperation and other contractual work. Through a local American agency called Hits Incorporated, Toei even contacted Warner Brothers for possible cooperation. ${ }^{19}$ Such international marketing activities, especially those aimed at the Western industrialized countries, imply that, due to its heavy financial commitments, the animation studio was also in search of wealthy partners for co-production and other contractual projects at a higher corporate level. ${ }^{20}$

The events recorded in Eiga Nenkan also reveal that Toei's senior management were consistently patient and persistent in courting the American investors. For example, when Hits Incorporated was not able to raise the money for a joint project proposal and wanted to abandon the planned partnership, Toei was willing to wait for a better opportunity and even took the initiative of maintaining ongoing communication. By contrast, the initial joint project with a Hong Kong producer ground to a halt and its final status was hardly reported or 
followed up on at all. ${ }^{21}$ The determination with which the studio had wooed Western partners shows an underlying continuous trait in Japan's modernization history. While in its display of military and moral might, it had failed miserably toward the end of the Second World War, in aesthetic enticement and economic prowess, the country continued (and still continues) to make a longlasting and growing impression on the West. ${ }^{22}$ Toei's semi-nationalistic perseverance at last paid off; by the mid-1960s, certain staff members of the studio's workforce were assigned to work on American animation contract work. Among the earliest joint production works were King Kong (1967), Tom Thumb (1967) and Rats on the Mayflower (1968), which were shown on the ABC television network in the United States (Toei, 1989: 55).

\section{Conclusion}

In summary, although Hakujaden succeeded in demonstrating to the Japanese public the high standard of production that Toei could achieve, many expressed mixed feelings about the studio's approach to the animated tale. One newspaper reporter critically questioned the overall narrative treatment of the tale, particularly the resulting 'unChineseness' and the 'un-Japaneseness', and made the challenge that by simplifying the conclusion, the studio had neglected the deeper sensitive meanings of the tale. ${ }^{23}$ Other film reviewers understood the 'export-oriented' intentions of the animated version, but dismissed it as an un-nationalistic venture in choosing to animate a non-Japanese classic tale. As this article has tried to demonstrate, the new patronnarrator of the Legend of the White Snake set its goals within a longterm economic perspective and was only mindful of its ethnic origin to a certain extent. What mattered was commercial entertainment. Animation in Japan eventually blossomed as a phenomenon of competitive growth, especially with the later arrival of television as a medium.

In 'exhibiting' its abilities to animate a non-Japanese tale, the studio went a long way towards proving to the Western world the ability of an Eastern animation industry to tell stories and express art in peaceful times. In a collective corporate sense, the resurrection of the Legend of the White Snake on Japanese soil was an advantageous performative venture. The result was not only to attract subsequent international business contracts, but also to win the precious opportunity to animate Western-based children's stories so that ideologically, economically and aesthetically, the East-West communication link with Japan would prevail. As Dower (1999) states in his analysis of the global economic success of Japan in the late 20th century, 'the genie had come out of the bottle again, only this time in a business suit rather than in khaki' (p. 557). In actuality, the manifestation of this success 
need not be as material as a business suit, for the 'uncanny and the fantastic' is equally representative and, in fact, more subtle and sensual than that. In the process of being nationally displaced and borrowed by another, Madam White Snake's powers were nonetheless dynamic and far-reaching. Primarily through animation and metamorphosis, she was effectively re-narrated to reach out to the Occidental world.

\section{Acknowledgements}

Extracts of this paper were originally presented at the 11th International Conference of the European Association for Japanese Studies, 31 August to 3 September 2005, at the University of Vienna under the panel, 'Performing the Popular'. I would like to thank the panel organizers Gunhild Borggreen and Yamanashi Makiko for giving me the opportunity to 'test' the concept of performativity in analysing Japanese postwar animation. The paper's anonymous reviewers' comments were critical and invaluable, and I especially thank Bob Rehak for his patience and encouragement, and Suzanne Buchan for her initial interest in my research.

\section{Notes}

1 Donald Crafton gave a keynote address at the 14th Society for Animation Studies Conference 2002 held in the DreamWorks SKG Animation Campus at Glendale, California. His paper was entitled 'Performance in and of Animation' and was subsequently published in SAS Newsletter in 2003.

2 All Japanese and Chinese names are written in the order of the family names first. For Chinese, the banyu pinyin pronunciation form is adopted. Macrons to indicate long vowels in Japanese words are included except for well-known places and names, e.g. Tokyo, Shochiku, Toei, etc.

3 On the other hand, a discerning eye may find my aesthetic reading of Hakujaden's background artwork too sweeping. For example, Imamura Taihei, one of Japan's earliest animation theorists, in his book Manga eiga ron (1992) praises the traditional aesthetic elements found in Hakujaden, citing the exquisite ink painting work and luxurious Momoyama designs as representative of Japanese art (p. 210). In my view, Japanese adaptation of Chinese art and culture has often been imitative, selective and innovative. In Hakujaden, I would argue that the aesthetic attempts to portray a classic Chinese picturesque setting were indeed genuine and amicable.

4 In Chinese characters, Toei means 'Eastern Film Company', and it was a merger of Toyoko and Oizumi film production companies in 1951 (Hosogaya, 2000: 65).

5 Toho has not yet made available the 1956 live-action film in video format; it would be helpful to see and compare the narrative content with the animated version.

6 Otsuka Yasuo was one of the key animators involved in the film project. The reasons were never reported in the media and he was unsure of the details (interview with the author, 11 August 2004, in Tokyo).

7 Madam White Snake's attraction to Xu Xian was due to remembrance of a past when the child Xu Xian saved her from a thunderstorm. During that 
incident, she was in the form of a snake. Years later, bored with a mundane, peaceful life, she wished to live in the human realm in order to repay her debt to her saviour Xu Xian.

8 Pai-nyan is said to be a 1000 -year-old snake spirit with special physical and spiritual powers, which she has taught herself and collected over the years.

9 For example, Toho cooperated with an Italian film company to make Madame Butterfly (1955), and Shochiku cooperated with the French to make Unforgettable Love (1956).

10 I would like to thank film specialists Ishizaki Kenji and Matsuoka Tamaki, who pointed out to me the existence of this exclusive trade journal.

11 They had experience in producing animation films before the end of the war, and some had worked on animated feature films sponsored by the military.

12 Taylorist principles of management were named after Frederick W. Taylor (1856-1915) who was an engineer and a pioneer in management theory. He advocated scientific management in order to ensure systematic work processes and output.

13 Generally, from an Anglo-American perspective, the war fought against the Japanese has often been termed the Pacific War (1941-5), which began when Japanese military forces attacked Pearl Harbor in December 1941 and other colonized parts of Southeast Asia. But to many East Asians, including Koreans, Chinese and the Japanese, the war was also known as the Greater East Asian War. The Japanese military forces' intrusion into continental China dated back much earlier, to the turn of the 20th century.

14 In the original White Snake Tale, there is an important episode in which Fa-hai insists on Xu Xian becoming a monk; when he refuses, and later finally agrees, he is locked up in the monastery grounds.

15 In terms of Jungian psychoanalysis, C.S. Jung stresses the negative imposition of the state's power on individual freedom and expression. The 'collective unconscious' plays an important role in influencing the psychic lives of individuals; the individual (the personal) and the collective are interconnected. See for example, C.S. Jung (1958).

16 Interview with the author, 11 August 2004, in Tokyo. To date, Hakujaden has been released in the VCD format by Asia Production Limited, a Hong Kong media company. The version maintains its original Japanese soundtrack but a second language option in Mandarin is included and Chinese subtitles are provided.

17 Another reason for the scarcity or absence of dissemination is that the region's film distribution network was controlled mainly by Chinese companies. One exception is that Japanese erotic films tend to gain exhibition space in the region. This is partly due to the inability of the local film companies to liberally film narratives related to sex and violence. See Ng (2004: 217-24).

18 Several examples are a Berliner Cultural Award, a special award at a children's international film festival in Venice and a Mexican Government recognition award among others (Toei, 1989: 44).

19 Its English name is directly translated from the notes given in the Eiga Nenkan (1959, 1960), pp. 117 and 122, respectively. 
20 In reality, by the mid-1970s, the creation of manga stories in Japan alone was able to sustain the broadcasting media. Without the initial sponsorship of overseas investors, animation studios in Japan also produced industrialized Western children's stories, for example, Alpine Girl Heidi (1974) and Anne of Green Gables (1979).

21 By the latter half of the mid-1950s, Toei also became financially stable, as Okawa successfully expanded its network of cinemas in Japan. Not only Hakujaden, but also Toei's several proposed joint film projects with the Hong Kong producer Zhang Guoli and even the Shaw Brothers somehow did not materialize (Yau, 2000: 106).

22 Japan's engagement with the West began with rangaku, a Dutch Studies learning movement in the 18th century when the Japanese were exposed to European art and sciences. It went through several major episodes, including the Russo-Japanese War 1904-5 (in which Japan emerged as the victor) and at certain international conferences where Japan was denied 'equal' treatment status in its quest to expand its naval fleet and to acquire foreign lands rich in natural resources. For an in-depth analysis of the historical context of Japan's aesthetic turn in its modernization efforts, see Iida Yumiko (2002).

23 Hosogaya (2000: 80). The reporter's penname was Kitao, and his film review was published in Mainichi shinbun, 22 October 1958.

\section{References}

Anderson, Joseph I. and Richie, Donald (1982) The Japanese Film: Art and Industry. Princeton, NJ: Princeton University Press.

Carlson, Marvin (2004) Performance: A Critical Introduction, 2nd edn. London: Routledge.

Crafton, Donald (1982) Before Mickey: The Animated Film 1898-1928. Chicago: University of Chicago Press.

Crafton, Donald (2003[2002]) 'Performance in and of Animation', Society for Animation Studies Newsletter 16(1): 8-13.

Dower, John W. (1999) Embracing Defeat: Japan in the Wake of World War II Defeat. New York: W.W. Norton.

Eiga nenkan (Motion Picture Almanac) (1954-60) Tokyo: Japanese Film Producers' Association.

Furniss, Maureen (1998) Art in Motion: Animation Aesthetics. Sydney: John Libbey.

Hosogaya Atsushi (ed.) (2000) Nibon anime no bishoki wo saguru (Exploring the Development of Japanese Animation). Tokyo: Yomiuri shibunsha and Bitsujukan renraku kyōgikai.

Huss, Ann L. (1997) 'Qingshe: A Story Retold', Chinese Culture XXXVIII(1): 75-94.

Iida Yumiko (2002) Rethinking Identity in Modern Japan: Nationalism as Aesthetics. London: Routledge.

Imamura Taihei (1992) Manga eiga ron (Comic Film Theory). Tokyo: Iwanami shoten.

Jung, C.S. (1958) The Undiscovered Self, trans. R.F.C. Hull. New York: New American Library.

Lu Feng (1980) 'Bianhua duoduan de yazhou yingzhan' (The Many Transformational Phases of the Asian Film Festival), Dianying pinglun (Film Review Journal) 8, December: 197-237. 
Otsuka Yasuo (2001) Sakuga asemamire (Creating Pictures Is Sweat Work). Tokyo: Tokuma shoten/Studio Ghibli.

Overseas Chinese Figures in Cinema (1992). Hong Kong: Urban Council, The 16th Hong Kong International Film Festival.

Schechner, Richard (2002) Performance Studies: An Introduction. London: Routledge.

Shirane Haruo (ed.) (2002) Early Modern Japanese Literature: An Anthology 1690-1900. New York: Columbia University Press.

Thompson, Kristin and Bordwell, David (1994) Film History: An Introduction. New York: McGraw-Hill.

Toei Animation Yearbook (1989). Tokyo: Toei Animation Company.

$\mathrm{Ng}$, Wai-ming Benjamin (2004) 'Japanese Elements in Hong Kong Erotic Films', Asian Cinema Journal 15(1): 217-24.

Yau, Kinna S.T. (2000) 'Hong Kong and Japan: Not One Less', in Border Crossings in Hong Kong Cinema, pp. 104-10. Hong Kong: Urban Council, The 24th Hong Kong International Film Festival.

Yamaguchi Katsunori and Watanabe Yasushi (1977) Nibon animeshon eiga shi (The History of Japanese Animation). Osaka: Yubunsha.

Yokota Masao (2004) 'A Master Animator: Yasuji Mori's Works for Children', International Journal of Comic Art 6(2): 376-91.

Zhao, Qingge (1998[1956]) Baishechuan: The Legend of the White Snake. Bilingual edition. Beijing: New World Press.

Tze-yue G. Hu has a PhD from the University of Hong Kong, Department of Comparative Literature, and taught at the National University of Singapore and Nanyang Technological University. From 2003 to 2004, she was a Japan Foundation fellow based at Waseda University, Division of Cinema and Theatre Studies. She is now affiliated to the University of Oklahoma, School of International and Area Studies and is working on a book on Japanese animation.

Address: School of International and Area Studies, 729 Elm Avenue, Room 116, Norman, OK 73019-2105, USA. [email: Tze.Yue.G.Hu-1@ ou.edu] 